\title{
URBAN FOOTPRINT OF MUMBAI - THE COMMERCIAL CAPITAL OF INDIA
}

\author{
T. V. RAMACHANDRA ${ }^{1,2,3}, H$. A. BHARATH ${ }^{1,2}, M$. V. SOWMYASHREE ${ }^{1}$ \\ ${ }^{1}$ Energy \& Wetlands Research Group, Center for Ecological Sciences (CES) \\ ${ }^{2}$ Centre for Sustainable Technologies (Astra) \\ ${ }^{3}$ Centre for infrastructure, Sustainable Transportation and Urban Planning \\ (CiSTUP) Indian Institute of Science, Bangalore, Karnataka, India
}

\begin{abstract}
Urban footprint refers to the proportion of paved surface (built up, roads, etc.) with the reduction of other land use types in a region. Rapid increase in the urban areas is the major driver in landscape dynamics with the significant erosion in the quality and quantity of the natural ecosystems. The urban expansion process hence needs to be monitored, quantified and understood for effective planning and the sustainable management of natural resources. Cities and towns have been experiencing considerable growth in urban area, population size, social aspects, negative environmental and geographical influence, and complexity. Mumbai, the commercial capital of India, has experienced a spurt in infrastructural and industrial activities with globalization and opening up of Indian markets. Unplanned urbanization has resulted in dispersed growth in peri-urban pockets due to socio-economic aspects with the burgeoning population of the city. Consequent to this, there has been an uneven growth pattern apart from the increase in slums in and around the city. This has necessitated the understanding of the urbanization pattern and process focusing especially on the expanding geographical area, its geometry and the spatial pattern of its development. This communication discusses the urban footprint dynamics of Mumbai using multi-temporal remote sensing data with spatial metrics. Land use analysis indicated a decrease of vegetation by $20 \%$ with an increase in urban extent by $155 \%$ during the last three decades. Landscape metrics aided in assessing the spatial structure and composition of the urban footprints through the zonal analysis by dividing the region into four zones with concentric circles of $1 \mathrm{~km}$ incrementing radius from the city centre. The study reveals a significant variation in the composition of the urban patch dynamics with increasing complexity and aggregation of urban area at the centre and sprawl at the outskirts. Shannon's entropy further confirms of sprawl with time. Further zoning with the circular gradients aided in understanding the transition process of land use categories into urban patch.
\end{abstract}

Key Words: urbanization, urban sprawl, urban pattern, remote sensing, spatial metrics, Mumbai

\section{Introduction}

Urbanization involves transformation of various land uses into urban areas. Unplanned and uncontrolled urban expansion leads to environmental degradation causing shortages of housing, worsening water quality, excessive air pollution, improper waste management etc. (Ramachandra et al. 2012, Uttara et al. 2012). The process of urbanization has a major impact on the land use patterns, affecting functional aspects of the landscape (Hara et al. 2005, Frohn and Hao 2006), including the process of waste assimilation. This necessitates mapping and monitoring of urban footprint through quantification of paved surface (built up, roads, etc.). The proportion of paved surface (built up, roads, etc.) with the reduction of other land use types in a 
region is referred as urban footprint. A concentrated growth of urban footprint often leads to the dispersed growth or urban sprawl at outskirts. Urban sprawl is often referred to as uncontrolled, scattered sub-urban development which lacks basic amenities such as treated water supply, sanitation, infrastructure, etc. with serious implications on local ecology and environment (Peiser 2001, Yedla 2003, Sudhira et al. 2004, Huang et al. 2008, Ramachandra et al. 2012, Bharath et al. 2012). Advanced understanding and visualization of sprawl helps in better regional planning with appropriate basic infrastructure and amenities (like supply of treated water, electricity, sanitation facilities). These regions are often left out of most of the governmental surveys (ex: national population census) as these pockets are not grouped under either urban or rural areas. The understanding of sprawl dynamics is very crucial to provide better governance with basic amenities and it also balances the provision of natural resources and human needs through visualized and orderly regional planning. Urban sprawl was evaluated and characterized exclusively based on major socio-economic indicators such as population growth, commuting costs, employment shifts, city revenue change, and number of commercial establishments (Han and He 1999, Brueckner 2000, Lucy and Phillips 2000, Lin and Ho 2003, Lichtenberg and Ding 2008). However, these approaches do not identify and quantify the impacts of urban sprawl in a spatial context that is required for local area planning.

Availability of temporal remotely sensed data acquired through space-borne sensors helps detecting the urban landscape dynamics in relation to urbanization (Chen et al. 2000, Epstein et al. 2002, Lo and Yang 2002, Ji et al. 2001, Lo and Yang 2002, Yeh and Li 2001, Sudhira et al. 2003, Ramachandra et al. 2012). This aids in characterizing the spatiotemporal trends of urbanization process and sprawl (Zerah 2008). Computation of metrics and modelling based on multi temporal spatial data provides a basis for predicting urbanization processes. This information supports policy making for an effective urban planning with natural resources conservation. Further temporal dynamics information with spatial metrics provides insights to the urbanization pattern (i.e., property, complexity and size of the existing urban area), which helps the sustainable regional development (Hill et al. 2004, DeFries 2008, Bhatta 2009a, 2009b, Ramachandra et al. 2012).

Urban pattern analysis provides the spatial properties and configuration of the area at a particular time (Galster et al. 2001) as urban patterns deal with the physical structure and the spatial characteristics of the urban processes that vary over time (Aguilera et al. 2011). Urban patterns have been analysed using spatial metrics (Jiang et al. 2007, Angel et al. 2007, Bharath et al. 2012, Ramachandra et al. 2012). Spatial metrics are useful in detecting the evolution of the urban sprawl pattern with time. These metrics, developed for thematic categorical maps, are applicable to a particular scale and resolution (Herold et al. 2003). Spatial metrics concepts are mostly used in the landscape ecology, but recently, it is being applied in the urban environments for mapping the urban process and structure (Alberti and Waddell 2000, Herold et al. 2002). Further, to understand, to locate and to quantify the specific areas of sprawl, density gradients (Ramachandra et al. 2012) are potentially useful in quantifying the urban development. The combination of remote sensing, density gradients and spatial metrics techniques provides an accurate and detailed mapping of the data which are immensely useful in urban applications (Ji et al. 2006, Ramachandra et al. 2012, Weng 2012). This communication is based on the potential of remote sensing, density gradients and spatial metrics for understanding the urban sprawl including the direction of growth. This paper is subdivided into four sections. The first section outlines the study area and data, the second section focuses on the methods used for understanding urban dynamics and the final section presents the results and conclusion. 


\section{Study area}

Mumbai is the capital of the Indian state of Maharashtra. It is located at $18^{\circ} 55^{\prime} \mathrm{N}$ and $72^{\circ} 50^{\prime} \mathrm{E}$ and it is bounded by the Arabian Sea in the west. It is the most populous city in India, and the sixth most populous city in the world and it is also considered as the commercial capital of India that serves as an economic hub of India. In the last three decades, the city saw tremendous growth in the infrastructure development and urban expansion. Mumbai has a population density of 4583 persons per square kilometre (Census of India 2001). Mumbai urban agglomeration is ranked third after Tokyo and Mexico City. The city started experiencing urbanization and industrial expansion during the 1860s, which gradually led to the rise of more urban areas. Mumbai is formed of seven islands and the expansion of Mumbai resulted in the bulging of the islands causing a scarcity of land. The study has been carried out for Mumbai city considering a $10 \mathrm{~km}$ buffer (Fig. 1).

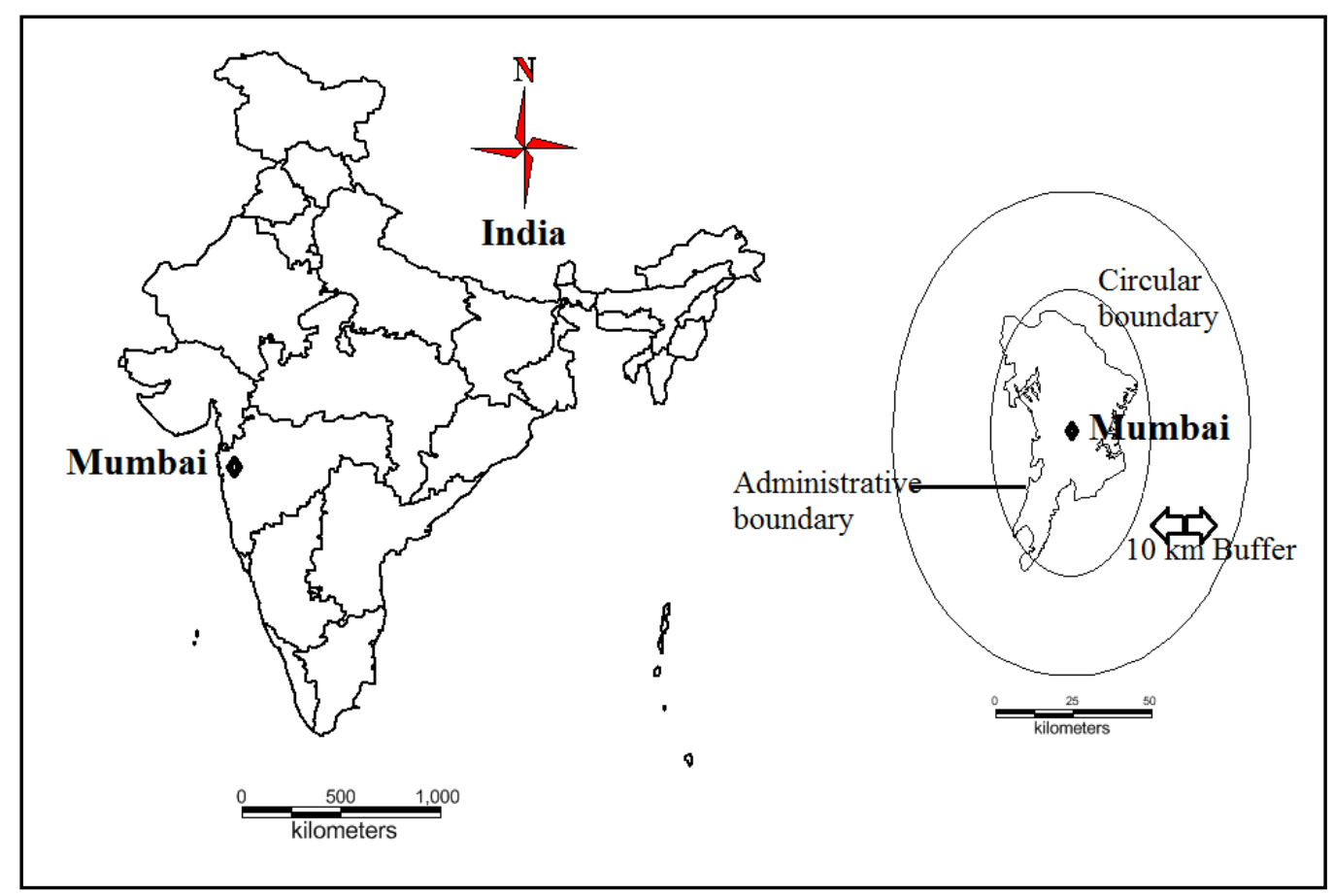

Fig. 1 - Study area: Mumbai with $10 \mathrm{~km}$ buffer

\section{Demography and Economy}

Mumbai is the most populous city and a cosmopolitan megacity of India. It is also considered the business capital of India because of its large trading activities. According to the 2011 census, Mumbai's population was about 12 million. Figure 2 depicts the temporal decadal population since 1901. Table 1 lists the geographical area, population and population density during the past four decades. In the beginning of 1990, the city experienced a major growth in the development of manufacturing industries and service sector industries, such finance, mass 


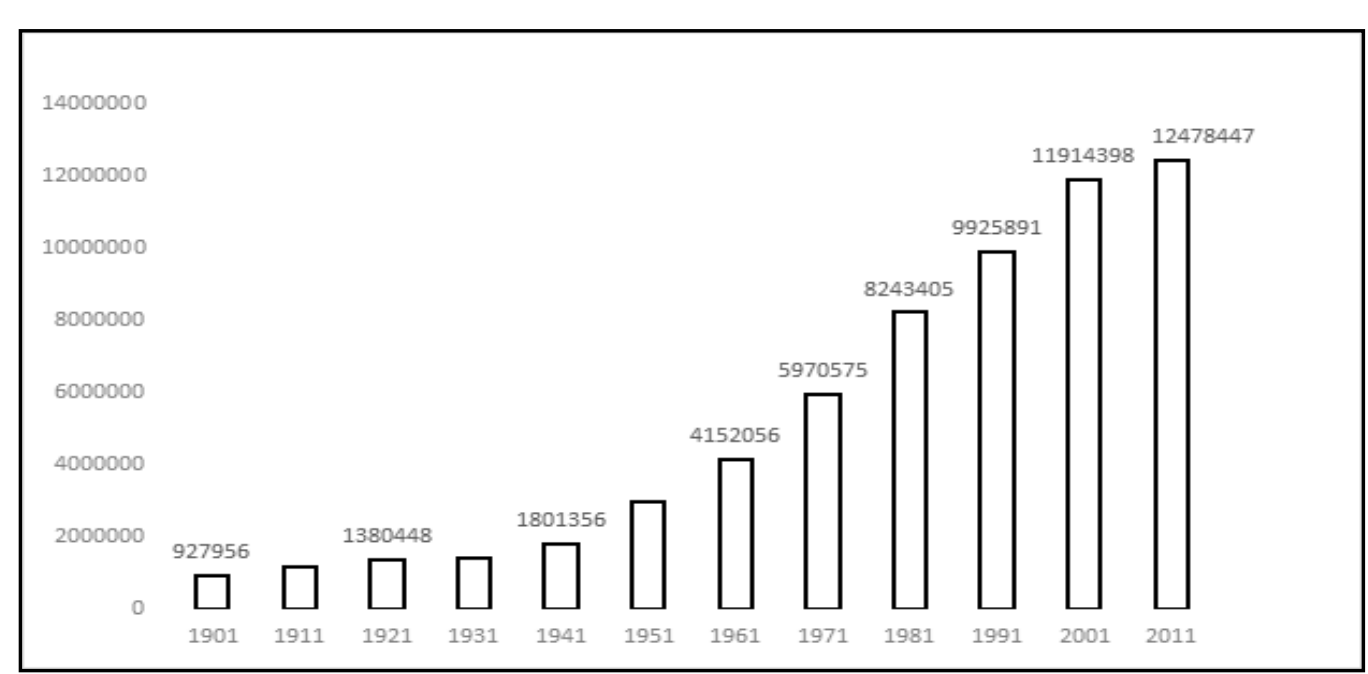

Fig. 2 - Temporal population since 1901

Source: Census of India (2001)

media, communication and information technologies, and real estate and property development sectors (Pacione 2006). The GDP per capita is 43, which is higher than for other cities.

Table 1

Area, Population and Population density of Mumbai

\begin{tabular}{|c|c|c|c|c|}
\hline City & $\begin{array}{c}\text { Area } \\
\text { (sq. km.) }\end{array}$ & Year & $\begin{array}{l}\text { Population } \\
\text { (lakhs) }\end{array}$ & $\begin{array}{l}\text { Population Density } \\
\text { (Persons per sq. km.) }\end{array}$ \\
\hline \multirow{5}{*}{ Mumbai } & \multirow{5}{*}{3571.05} & 1971 & 5970575 & 1671 \\
\hline & & 1981 & 8243405 & 2308 \\
\hline & & 1991 & 9925891 & 2780 \\
\hline & & 2001 & 11914398 & 3336 \\
\hline & & 2011 & 12478447 & 3494 \\
\hline
\end{tabular}

Source: Census India (1971-2011)

\section{Urban Development Planning and Infrastructure}

The urbanisation process in Mumbai has led to the expansion of the city and provision of many industries resulted in a large scale migration (Prasad et al. 2009). The city planning development process is controlled by the town planning departments and the Urban Development Authority. The Greater Mumbai Municipal Corporation also known as Brihat Mumbai Municipal Corporation (BMMC) is one of the most affluent civic bodies in the country and it covers an area of $4,355 \mathrm{~km}^{2}$ (Neelima 2003). Mumbai Metropolitan Region Development Authority (MMRDA) was setup in 1975 under the Mumbai Metropolitan Region Development Authority Act, which is responsible for the planning and development activities in the Mumbai region (Neelima 2003). 


\section{Data}

Data used for assessing the urban dynamics included multispectral data of Landsat series and collateral data (such as the Survey of India topographic sheets), which are listed in Table 2.

Data used for assessing urban dynamics

Table 2

\begin{tabular}{|l|c|c|}
\hline \multicolumn{1}{|c|}{ Data } & Year & Purpose \\
\hline $\begin{array}{l}\text { Landsat Series Multispectral } \\
\text { sensor (57.5m) }\end{array}$ & 1973 & Land cover and Land use analysis \\
\hline $\begin{array}{l}\text { Landsat Series Thematic mapper } \\
(28.5 \mathrm{~m})\end{array}$ & 1992, & Land cover and Land use analysis \\
and Enhanced Thematic Mapper & 2009 & \\
sensors & - & To Generate boundary and Base layer \\
\hline $\begin{array}{l}\text { Survey of India (SOI) topo sheets } \\
\text { of 1:50000 and 1:250000 scales }\end{array}$ & & $\begin{array}{c}\text { For geo-correcting and generating } \\
\text { validation dataset }\end{array}$ \\
\hline $\begin{array}{l}\text { Field visit data - captured using } \\
\text { GPS }\end{array}$ & - & \\
\hline
\end{tabular}

\section{Method}

Urban dynamics was assessed using temporal remote sensing data of the period 1973 to 2010 . The time series spatial data acquired from Landsat Series Multispectral sensor $(57.5 \mathrm{~m})$ and thematic mapper $(28.5 \mathrm{~m}$ ) sensors for the period 1973 to 2010 were downloaded from a public domain (http://glcf.umiacs.umd.edu/data). The Survey of India (SOI) topographic sheets of $1: 50000$ and 1:250000 scales were used to generate base layers of city boundary, etc. The process of the analysis is threefold as described in Figure 3, which includes pre-processing, analysis of land cover and land use, and finally, the gradient wise zonal analysis of Mumbai.

1. Pre-processing: Remote sensing data (Landsat series) for Mumbai, aquired for different time periods, were downloaded from Global Land Cover Facility (http://www.glcf.umd.edu/ index.shtml and http://www.landcover.org/), United States Geological Survey (USGS) Earth Explorer (http: // edcsns 17. cr. usgs. gov/ NewEarthExplorer /) and Glovis (http:// www.glovis.usgs.gov). The remote sensing data obtained were geo-referenced, geo-corrected, rectified and cropped pertaining to the study area. Geo-registration of remote sensing data (Landsat data) has been done using ground control points collected from the field using pre calibrated GPS (Global Positioning System) and also known points (such as road intersections, etc.) collected from geo-referenced topographic maps published by the Survey of India. The Landsat satellite data of 1973 (with spatial resolution of $57.5 \mathrm{~m} \times 57.5 \mathrm{~m}$, nominal resolution) and of $1992-2009$ (28.5 m x $28.5 \mathrm{~m}$, nominal resolution) were resampled to $30 \mathrm{~m}$ in order to maintain uniformity in spatial resolution across different time periods. The study has been carried out for the Mumbai administrative area with $10 \mathrm{~km}$ buffer, which helps in accounting the region experiencing sprawl.

2. Land Cover analysis: Land Cover analysis was performed to understand the changes in the vegetation cover. Normalised Difference Vegetation Index (NDVI) was found suitable and it was used for measuring vegetation cover. NDVI values range from -1 to +1 . Very low values of NDVI (-0.1 and below) correspond to soil or barren areas of rock, sand, or urban built up. Zero 


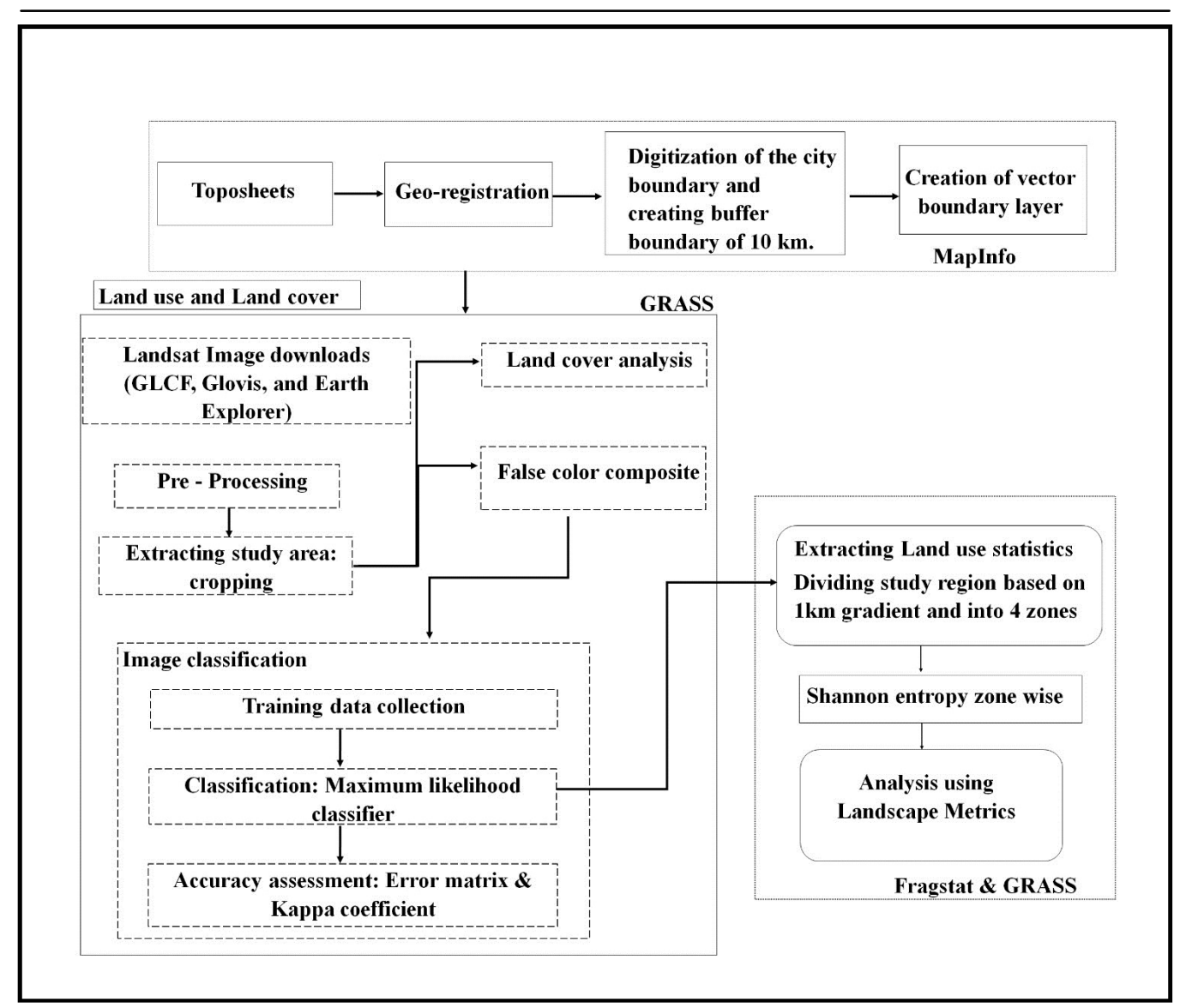

Fig. 3 - Procedure adopted for classifying the remote sensing data and the computation of metrics

indicates water cover. Moderate values represent low density vegetation ( 0.1 to 0.3$)$, while high values indicate thick canopied vegetation (0.6 to 0.8$)$.

3. Land use analysis: The method involves a) generation of False Colour Composite (FCC) of remote sensing data (bands - green, red and NIR). This helped in locating heterogeneous patches in the landscape, b) selection of training polygons (these correspond to heterogeneous patches in FCC) covering $15 \%$ of the study area and uniformly distributed over the entire study area, c) loading these training polygons co-ordinates into pre-calibrated GPS, d) collection of the corresponding attribute data (land use types) for these polygons from the field. GPS helped in locating respective training polygons in the field, e) supplementing this information with Google Earth, f) $60 \%$ of the training data has been used for classification, while the balance is used for validation or accuracy assessment.

Land use analysis was carried out using supervised pattern classifier - Gaussian Maximum Likelihood Classifier (GMLC) algorithm. Remote sensing data was classified using signatures 
from training sites that include all the land use types detailed in Table 3. Mean and covariance matrix are computed using the estimate of maximum likelihood estimator. This technique has proved to be a superior classifier as it uses various classification decisions using probability and cost functions (Duda et al. 2000, Ramachandra et al. 2012).

Maximum likelihood classifier is then used to classify the data using these generated signatures. This method is considered as one of the superior methods as it uses various classification decisions using probability and cost functions (Duda et al. 2000). Mean and covariance matrix were computed using the estimate of maximum likelihood estimator. Land use was computed using the temporal data through the open source program GRASS Geographic Resource Analysis Support System (http://ces.iisc.ernet.in/foss). Signatures were collected from field visits and with the help of Google Earth. $60 \%$ of the total generated signatures were used in classification and $40 \%$ of the signatures were used in the validation and accuracy assessment. Classes of the resulting image were re-classed and recoded to form four land-use classes

Accuracy assessment methods evaluate the performance of classifiers (Mitrakis et al. 2008). This is done either through comparison of Kappa coefficients (Congalton et al. 1983). For the purpose of accuracy assessment, a confusion matrix was calculated. Accuracy assessment and Kappa coefficient are common measurements used in various publications to demonstrate the effectiveness of the classifications (Congalton 1991, Lillesand and Kiefer 2005). Recent remote sensing data (2010) was classified using the collected training samples. Statistical assessment of classifier performance is done based on the performance of spectral classification considering reference pixels which include computation of kappa ( $\mathrm{K}$ ) statistics and overall (producer's and user's) accuracies. For earlier time data, training polygon along with attribute details were compiled from the previously published topographic maps, vegetation maps, revenue maps, etc.

Table 3

Land use classification categories adopted

\begin{tabular}{|l|c|}
\hline \multicolumn{1}{|c|}{$\begin{array}{c}\text { Land use } \\
\text { Class }\end{array}$} & Land uses included in the class \\
\hline Urban & $\begin{array}{r}\text { Residential area, industrial area, and all paved surfaces } \\
\text { and mixed pixels having built up area }\end{array}$ \\
\hline Water bodies & Tanks, Lakes, Reservoirs \\
\hline Vegetation & Forest, Cropland, Nurseries \\
\hline Others & Rocks, Quarry Pits, Open Ground at Building Sites, Kaccha Roads \\
\hline
\end{tabular}

4. Zonal Analysis: City boundary along with the buffer region was divided into 4 zones: Northeast (NE), Southwest (SW), Northwest (NW), Southeast (SE) for further analysis as the urbanization is not uniform in all directions. As most of the definitions of a city or its growth are defined in terms of directions, it was considered more appropriate to divide the region in four zones based on direction. Zones were further divided into concentric circles of $1 \mathrm{~km}$ incremental radius from the central pixel (Central Business district). The growth of the urban 
areas along with the agents of change is understood in each zone separately through the computation of urban density for different periods.

5. Division of these zones to concentric circles (Gradient Analysis): All of the zones were divided into concentric circles with a consecutive incrementing radius of $1 \mathrm{~km}$ from the center of the city. This analysis helped in visualising the process of change at a local level and to understand the agents responsible for the changes. This helps in identifying the causal factors and locations experiencing various levels (sprawl, compact growth, etc.) of urbanization in response to the economic, social and political forces. This approach (zones, concentric circles) also helps in visualizing the forms of urban sprawl (low density, ribbon, leaf-frog development). The built up density in each circle is monitored overtime using time series analysis. This helps the city administration in understanding the urbanization dynamics to provide appropriate infrastructure and basic amenities.

6. Shannon's Entropy: Further to understand the growth of the urban area in a specific zone and to understand if the urban area is compact or divergent, the Shannon's entropy (Sudhira et al. 2004, Ramachandra et al. 2012) was computed for each zone. Shannon's entropy (Hn), given in equation 1, explains clearly the development process and its characteristics.

$$
\mathrm{Hn}=-\sum_{\mathrm{i}=1}^{\mathrm{n}} \mathrm{Pi} \log
$$

Where $\mathrm{Pi}$ is the proportion of the built-up in the $\mathrm{i}^{\text {th }}$ concentric circle. As per Shannon's Entropy, if the distribution is maximally concentrated in one circle, the lowest value - zero - will be obtained. If the distribution is even among the concentric circles, $\mathrm{Hn}$ will have maximum of $\log n$.

7. Computation of spatial metrics: Spatial metrics are helpful to quantify spatial characteristics of the landscape. Selected spatial metrics were used to analyse and understand the urban dynamics, while FRAGSTATS (McGarigal and Marks 1995) was used to compute metrics at three levels: patch level, class level and landscape level. Table 4 below gives the list of the metrics along with their description considered for the study.

Table 5

NDVI output generated results gives idea about vegetation versus non vegetation

\begin{tabular}{|l|r|r|}
\hline Year & Vegetation (\%) & \multicolumn{2}{|c|}{ Non- vegetation (\%) } \\
\hline 1973 & 53.63 & 46.38 \\
\hline 1992 & 39.77 & 60.23 \\
\hline 1998 & 37.43 & 62.55 \\
\hline 2009 & 33.76 & 66.23 \\
\hline
\end{tabular}

\section{Results}

1. Land Cover Analysis: Land cover analysis was performed using NDVI and results are provided in Figure 4. NDVI ranges from -1 to 1 . The negative value indicates the presence of non-vegetation such as built-up, water, sand etc. The positive values indicate the presence of vegetation. Table 5 tabulates the results of NDVI analysis. NDVI generated indicates that there has been a loss of green cover in the study region. Vegetation declined from 53.63 (1973) to $33.76 \%$ (2009). There has been a loss in vegetation up to $62.79 \%$ during the past four 
Urban Footprint of Mumbai - The Commercial Capital of India

Table 4

Spatial metrics chosen for the urban pattern analysis

\begin{tabular}{|c|c|c|}
\hline Indicator & Formula & Description \\
\hline $\begin{array}{l}\text { Number of patches } \\
\text { (Built-up) (NP) }\end{array}$ & $\begin{array}{l}\quad \mathrm{N}=\mathrm{n}_{\mathrm{i}} \\
\text { Range: } \mathrm{NP}=1\end{array}$ & $\begin{array}{l}\text { NP equals the number of patches of the } \\
\text { corr esponding patch type. } n_{i} \text { is the number of } \\
\text { patches of a particular type. }\end{array}$ \\
\hline $\begin{array}{l}\text { Percentage of landscape (Built- } \\
\text { up) (PLAND) }\end{array}$ & $\begin{array}{c}\text { PLAND }=P_{1}=\frac{\sum_{j=1}^{\mu} a_{i j}}{A}(100) \\
\text { Range: } 0<\text { Land }=100\end{array}$ & $\begin{array}{l}\text { PLAND equals the percentage the landscape } \\
\text { comprised of the corresponding patch typ e. } a_{i j}=\text { area } \\
\left(\mathrm{m}^{2}\right) \text { of patch ij. } A=\text { total landscape area }\left(\mathrm{m}^{2}\right) .\end{array}$ \\
\hline Patch Density (PD) & $\begin{array}{c}\mathrm{PD}=\frac{\mathrm{n}_{\mathrm{i}}}{\mathrm{A}}(10,000)(100) \\
\text { Range: } \mathrm{PD}>0\end{array}$ & $\begin{array}{l}P D \text { is the number of patch of urb an patch divided by } \\
\text { total landscape area. }\end{array}$ \\
\hline $\begin{array}{l}\text { Largest patch Index } \\
\text { (Built-up) (LPI) }\end{array}$ & $\begin{array}{c}\text { LPI }=\frac{\max _{-1}^{n}\left(a_{y}\right)}{A}(100) \\
\text { Range: } 0<\text { LPI }=100 \\
\text { LSI }=\frac{e_{i}}{m_{n} e_{i}} \\
\text { Range: } L S I=1 \text {, without limit }\end{array}$ & $\begin{array}{l}\mathrm{LPI} \text { ap proaches } 0 \text { when the largest patch of the built- } \\
\text { up patch becomes increasing } \mathrm{y} \text { small and } \mathrm{LPI}=1 \\
\text { when the entire landscape of the patch type of the } \\
\text { built-up class. } \\
\mathrm{LSI} \text { equals the total length of edge (or perimeter) } \\
\text { involving the correspond ing class, given in number } \\
\text { of cell surfaces, divided by the minimum length of } \\
\text { class edge (or perimeter) possible for a maximally } \\
\text { aggregated class. }\end{array}$ \\
\hline $\begin{array}{l}\text { Mean Patch Size } \\
\text { (Class/Landscape) (MPS) }\end{array}$ & $\begin{array}{c}\text { MPS }=\frac{A}{N_{\text {patch }}}(10000 \\
\text { Range: } \text { MPS }>0, \text { without limit }\end{array}$ & $\begin{array}{l}\text { MPS equals the sum of the areas }\left(\mathrm{m}^{2}\right) \text { of all patches } \\
\text { of the corresponding patch type, divided by the } \\
\text { number of patches of the same type, divided by } \\
10000 \text { (to convert to hectares). }\end{array}$ \\
\hline $\begin{array}{l}\text { Normalised landscape shape Index } \\
\text { (NLSI) }\end{array}$ & $\begin{array}{l}\text { NLSI }=\frac{e_{i}-\min e_{i}}{\max e_{i}-\min e_{i}} \\
\text { Range: } 0 \text { to } 1 \\
E D=\frac{E}{A}(10,000)\end{array}$ & $\begin{array}{l}\text { Norm alized Landscape shape index is the } \\
\text { normalized version of the landsc ape shape index } \\
\text { (LSI) and, as such, provides a simple measure of } \\
\text { class aggregation or clumpedness. It measures the } \\
\text { perimeter-to-area ratio for the landscape as a whole. }\end{array}$ \\
\hline Edge Density & $\begin{array}{l}\text { Range: } E D \geq 0 \text { when there is no edge in the } \\
\text { landscape; that is when entire landscape and } \\
\text { landscape border if present consist of single } \\
\text { patch }\end{array}$ & $\begin{array}{l}\text { ED standardizes edge to a per unit area bas is that } \\
\text { facilitate comparison between landscapes of } \\
\text { different sizes. }\end{array}$ \\
\hline Clumpiness Index (Clumpy) & $\begin{array}{l}\mathrm{G}_{\mathrm{i}}=\left[\frac{\mathrm{g}_{\mathrm{ii}}}{\left(\sum_{\mathrm{k}=1}^{\mathrm{m}} \mathrm{g}_{\mathrm{ik}}\right)-\min \mathrm{e}_{\mathrm{i}}}\right] \\
\text { CLUMPY }=\left(\begin{array}{c}{\left[\frac{\mathrm{G}_{\mathrm{i}}-\mathrm{P}_{1}}{\mathrm{P}_{1}}\right] \text { for } \mathrm{G}_{\mathrm{i}}<\mathrm{P}_{1} \mathrm{P}_{1}<5 ; \text { else }} \\
\frac{\mathrm{G}_{\mathrm{i}}-\mathrm{P}_{1}}{1-\mathrm{P}_{1}}\end{array}\right) \\
\text { Range: Clumpiness ranges from }-1 \text { to } 1\end{array}$ & $\begin{array}{l}\text { Clumpy }=-1 \text { when the focal patch type is maximally } \\
\text { disaggregated, Clumpy }=0 \text { when the focal patch is } \\
\text { distributed randomly and ap proaches } 1 \text {, when patch } \\
\text { type is maximally aggregated. }\end{array}$ \\
\hline Aggregation Index (Al) & $A I=\left[\frac{g_{i i}}{\operatorname{maxg}_{\mathrm{ii}}}\right](100)$ & $\begin{array}{l}\mathrm{g}_{\mathrm{i}}=\text { number of like adjacencies (jains) between } \\
\text { pixels of patch type (class) } \mathrm{i} \text { based on the single- } \\
\text { count method. max }-\mathrm{g}_{\mathrm{i}}=\text { maximum number of like } \\
\text { adjacencies (joins) between pixels of patch type } \\
\text { (class) i (see below) based on the single-count } \\
\text { method. }\end{array}$ \\
\hline $\begin{array}{l}\text { Interspersion and Juxtaposition } \\
\text { Index } \\
\text { (Landsc ape level) } \\
\text { (IJI) }\end{array}$ & $\begin{array}{l}\mathrm{IJI}=\frac{-\sum_{\mathrm{K}=1}^{\mathrm{m}}\left(\left\lfloor\frac{\mathrm{eik}}{\sum_{k=2}^{\mathrm{m}} e_{\mathrm{ik}}}\right\rfloor \ln \left\lfloor\frac{e_{1 k}}{\sum_{k=2}^{m} e_{1 k}}\right]\right)}{\ln (\mathrm{m}-1)}(100) \\
\text { Range: } 0<\mathrm{JI}=100\end{array}$ & $\begin{array}{l}\text { eik }=\text { total length }(m) \text { of edge in landscape between } \\
\text { patch types } 1 \text { and } k \text {. } m=\text { number of patch type } \\
\text { present in landscape. }\end{array}$ \\
\hline
\end{tabular}




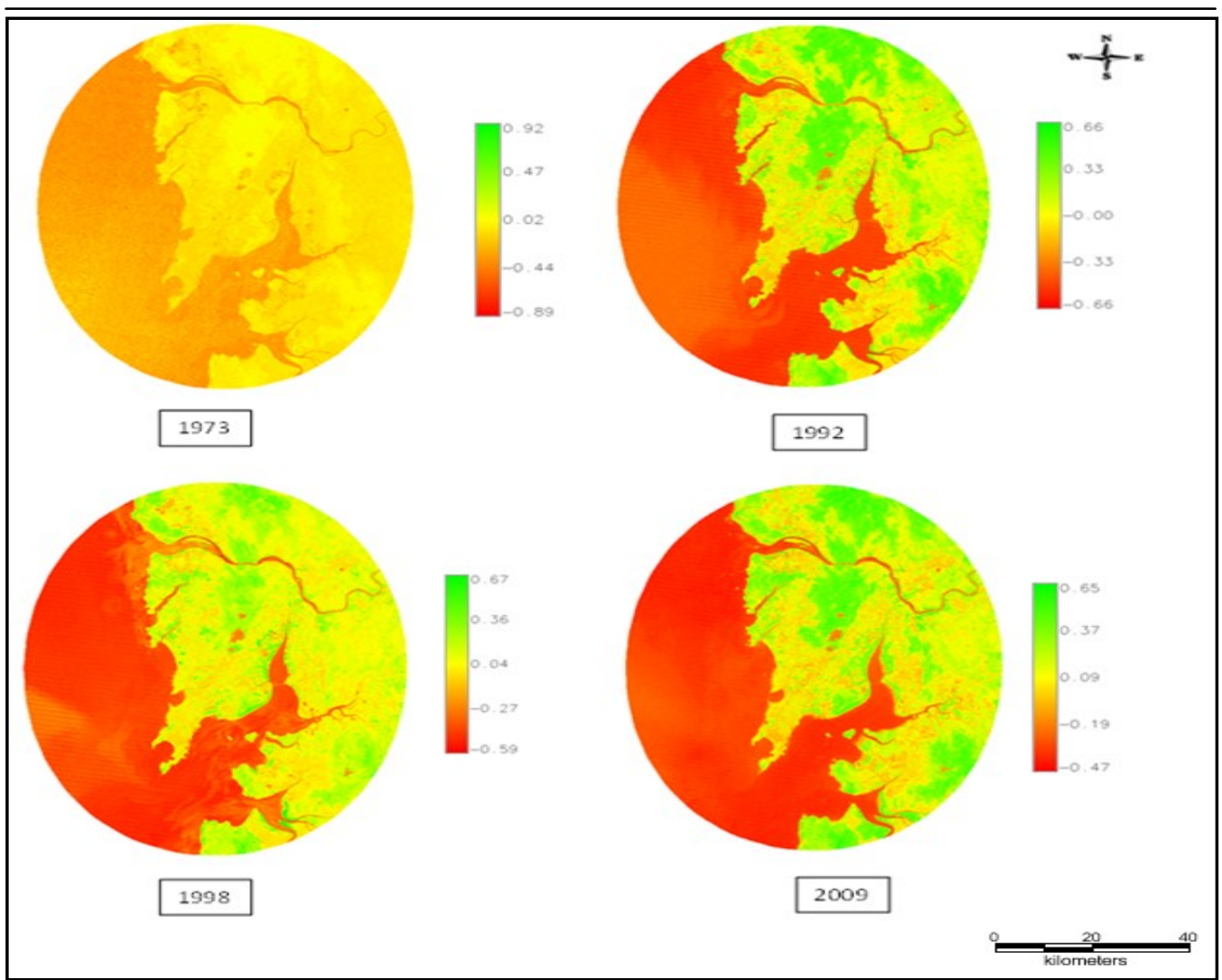

Fig. 4- NDVI from Landsat 1973, 1992, 1998 and 2009 for Mumbai region

decades. Vegetation class includes forests, agriculture, plantation, etc. Land use analysis would help in getting details under each land use category.

2. Land use analysis: Temporal remote sensing data of the study area were classified using GMLC with training data. Data that was kept for validation were used to generate another set of classified images. Accuracy assessment of both the sets of classified images was done using error matrix, overall accuracy and Kappa statistics. Figure 5 shows the classified images of the study region. Table 6 lists details of land use categories and Table 7 provides the overall accuracy and Kappa statistics of the classified data.

Land use statistics, as tabulated in table 6 , indicates that there has been a phenomenal growth of urban area of $155 \%$ during the past four decades. Figure 6 depicts the process and diffusion of urban pockets in the study region during the past four decades. Further, the study area was divided into 4 zones and into concentric circles of $1 \mathrm{~km}$ radius from the city centre. Figure 7 depicts the circle-wise land use statistics.

3. Shannon's entropy $(\mathrm{Hn})$ : Table 8 lists the Shannon's entropy calculated for the data of 1973 to 2009. Figure 8 indicates the direction-wise Shannon's entropy. This shows an increasing trend for NE and SW directions which indicates that urban patches are getting fragmented in time. In NW direction, Shannon's entropy values show an increasing trend till 1998 that slightly 


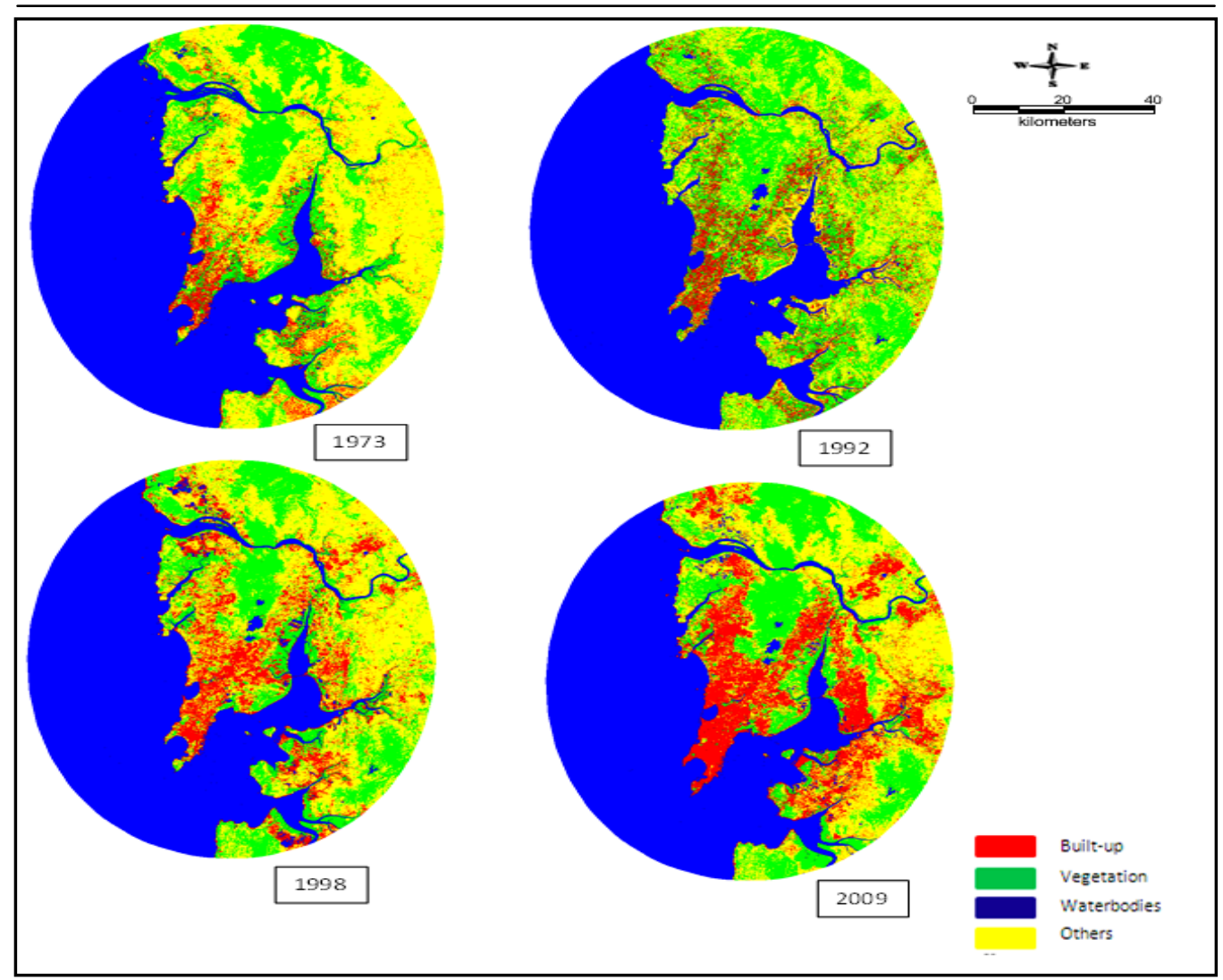

Fig. 5 - Spatial extent of land use categories in Mumbai

Table 6

Land Use statistics of the classified images

\begin{tabular}{|c|r|r|r|r|}
\hline $\begin{array}{c}\text { Land Use } \\
\text { category }\end{array}$ & $\begin{array}{c}\text { Built-up } \\
(\%)\end{array}$ & $\begin{array}{c}\text { Vegetation } \\
(\%)\end{array}$ & $\begin{array}{c}\text { Water body } \\
(\%)\end{array}$ & \multicolumn{1}{c|}{$\begin{array}{c}\text { Others } \\
(\%)\end{array}$} \\
\hline 1973 & 3.32 & 35.04 & 43.22 & 18.42 \\
1992 & 7.37 & 21.92 & 45.82 & 24.89 \\
1998 & 9.28 & 20.26 & 45.71 & 24.75 \\
2009 & 14.26 & 16.19 & 44.74 & 24.80 \\
\hline
\end{tabular}

Overall Accuracy and kappa statistics of classified images

Table 7

\begin{tabular}{|c|c|c|c|c|c|c|c|c|}
\hline \multirow{2}{*}{ City } & \multicolumn{2}{|c|}{ 1970s } & \multicolumn{2}{c|}{ 1980s } & \multicolumn{2}{c|}{ 1990s } & \multicolumn{2}{c|}{ 2000s } \\
\cline { 2 - 9 } & OA & $\widehat{K}$ & OA & $\widehat{K}$ & OA & $\widehat{\mathcal{K}}$ & OA & $\widehat{\mathcal{K}}$ \\
\hline MUMBAI & 73 & 0.9471 & 98 & 0.8115 & 99 & 0.8225 & 99 & 0.8193 \\
\hline
\end{tabular}


T. V. RAMACHANDRA, $H$. A. BHARATH, $M$. V. SOWMYASHREE

Table 8

Shannon's entropy for Mumbai region

\begin{tabular}{|c|c|c|c|c|c|}
\hline & NE & NW & SE & SW & Reference value \\
\hline 1973 & 0.02 & 0.11 & 0.21 & 0.14 & \multirow{2}{*}{1.59} \\
\cline { 1 - 4 } 1992 & 0.20 & 0.16 & 0.26 & 0.13 & \multirow{2}{*}{} \\
\hline 1998 & 0.31 & 0.22 & 0.27 & 0.14 & \\
\hline 2009 & 0.32 & 0.30 & 0.43 & 0.22 & \\
\hline
\end{tabular}

Fig. 6-Urbanisation pattern of Mumbai in past 4 decades
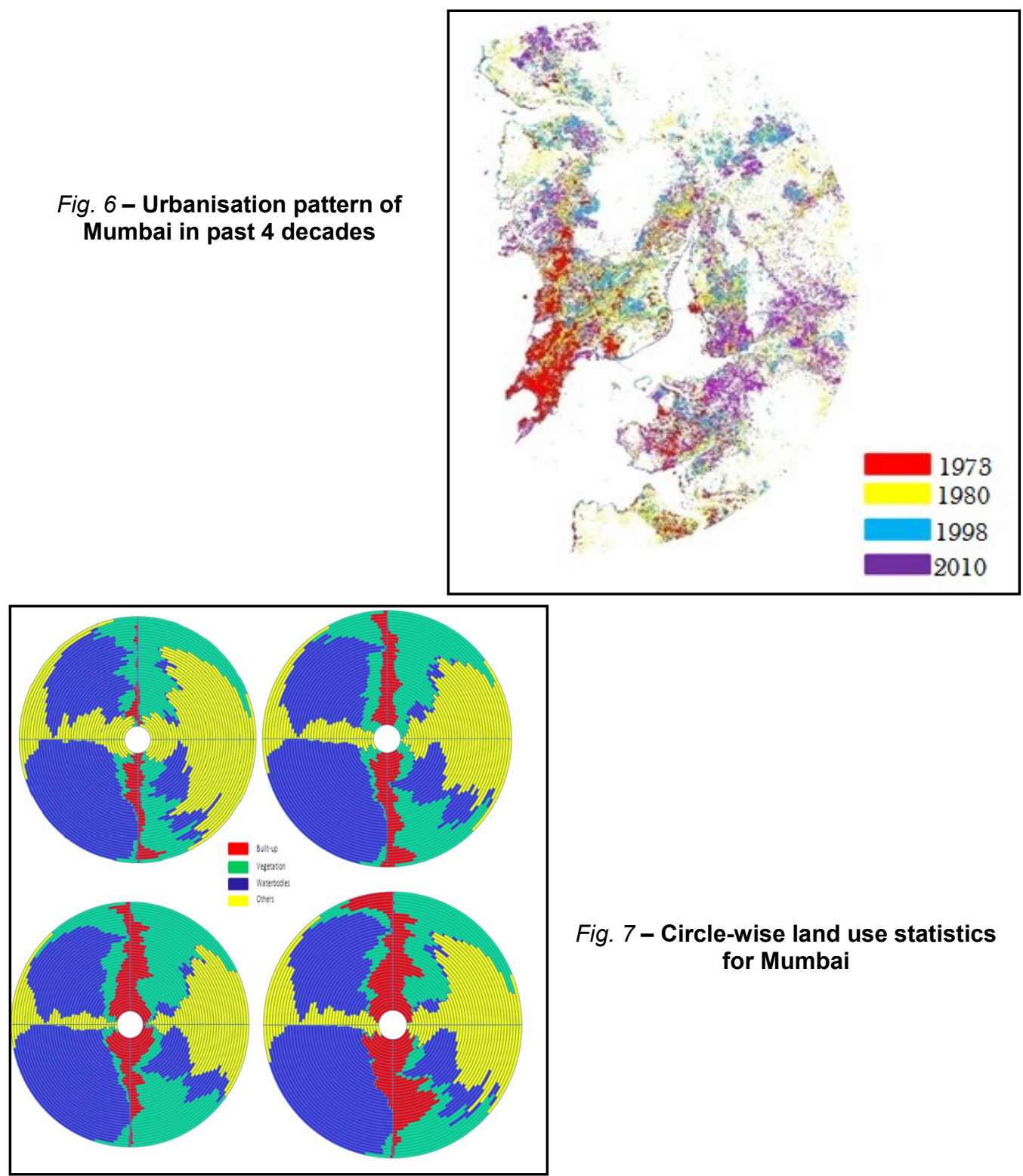

Fig. 7 - Circle-wise land use statistics for Mumbai 


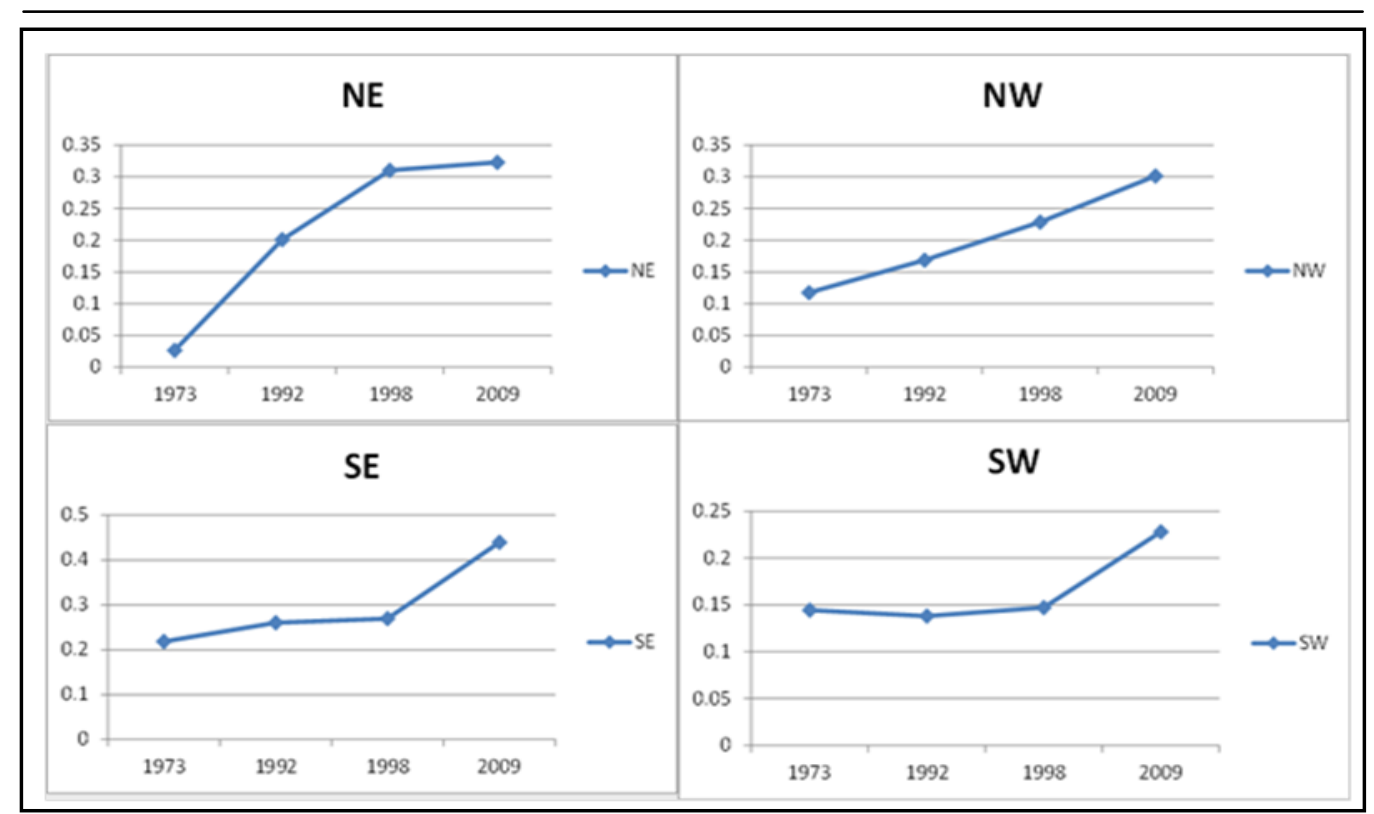

Fig. 8 - Shannon's entropy for the year 1973 to 2009

decreases in 2009 indicating compactness. In SE direction, there has been an increasing trend from 1973 to 1992 with a sudden decline in 1998 (which shows compactness) and a slight increase in 2009 with increasing fragmentation.

\section{Spatial metrics analysis}

4.1. Percentage of landscape (PLAND): PLAND (Fig. 9a) equals the percentage of landscape comprised of the corresponding class patches. Built up percentage was computed to understand the ratio of built up and its increase in the landscape. Percentage of landscape gives a similar trend as the class area. In northeast direction, maximum PLAND is depicted in C13, C17, C25 and C27 in 2009. In northwest direction, the maximum value was found in C11, C12, C13, C14 and C15. Similarly, in SE (C13 to C27) and in SW (C5 to C21), the landscape comprised of a high rate of the urban patches as depicted in the graph below.

4.2. Number of patches (NP): Number of patches (NP) equals the number of built up patches in hectares in a landscape. It indicates the level of fragmentation in built up landscape (Fig. $9 \mathrm{~b})$. In NE direction, C19 and C27 show a greater number of urban patches which imply that the patches are getting fragmented (more values found in 1992 and 1998 compared to 2009, whereas 1973 has a very low value which indicates the compact features of urban patches). In NW direction, the number of patches is varying for all circles (more variation is found in 1992 and 1998 compared to 2009, whereas, 1973 has a very low value which indicates the compact features of urban patches). In SE and SW directions, the number of patches is low, which indicates the compactness of patches except for circles (C21 to C29) in southeast direction (i.e., maximum values found for the year 2009 indicates fragmentation).

4.3. Patch Density (PD): Patch density (Fig. 9c) is an indicator of urban fragmentation and as the number of patches increases, patch density increases, which connotes to higher 


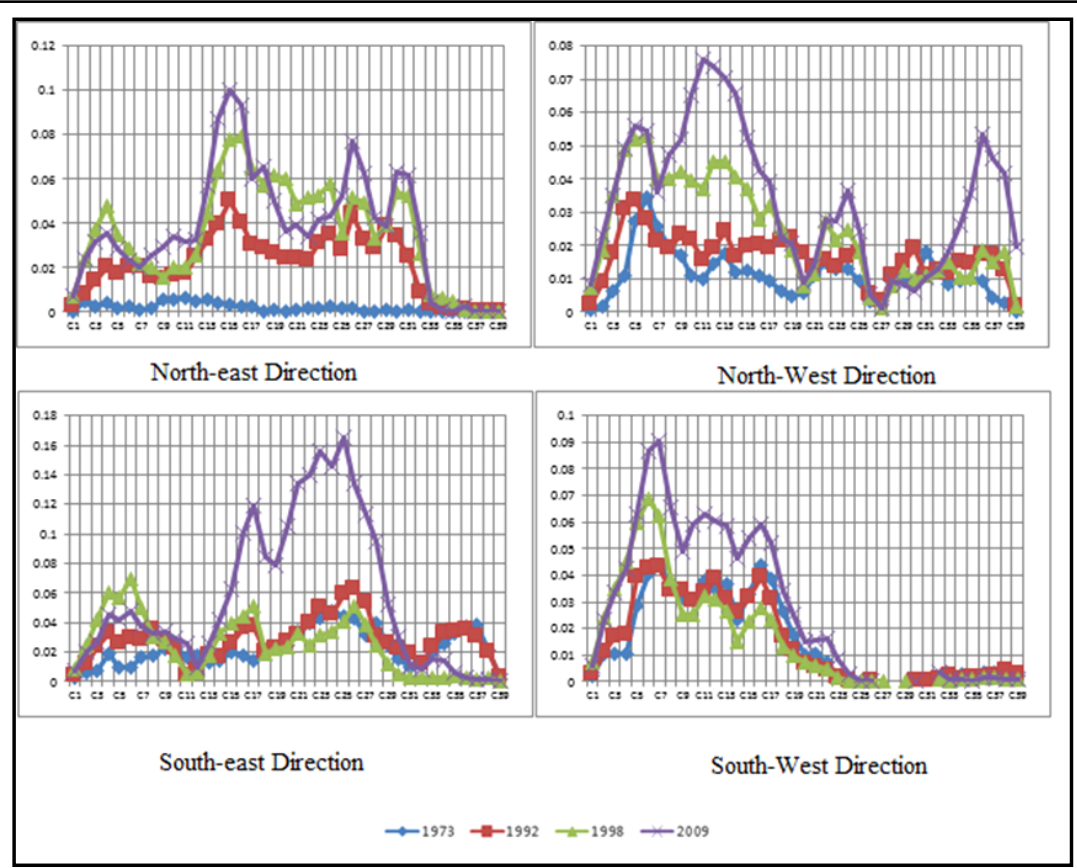

Fig. 9a-PLAND direction and Circle wise

(Note: $X$ axis indicates circles considered, $Y$ axis indicates the value of the metrics)

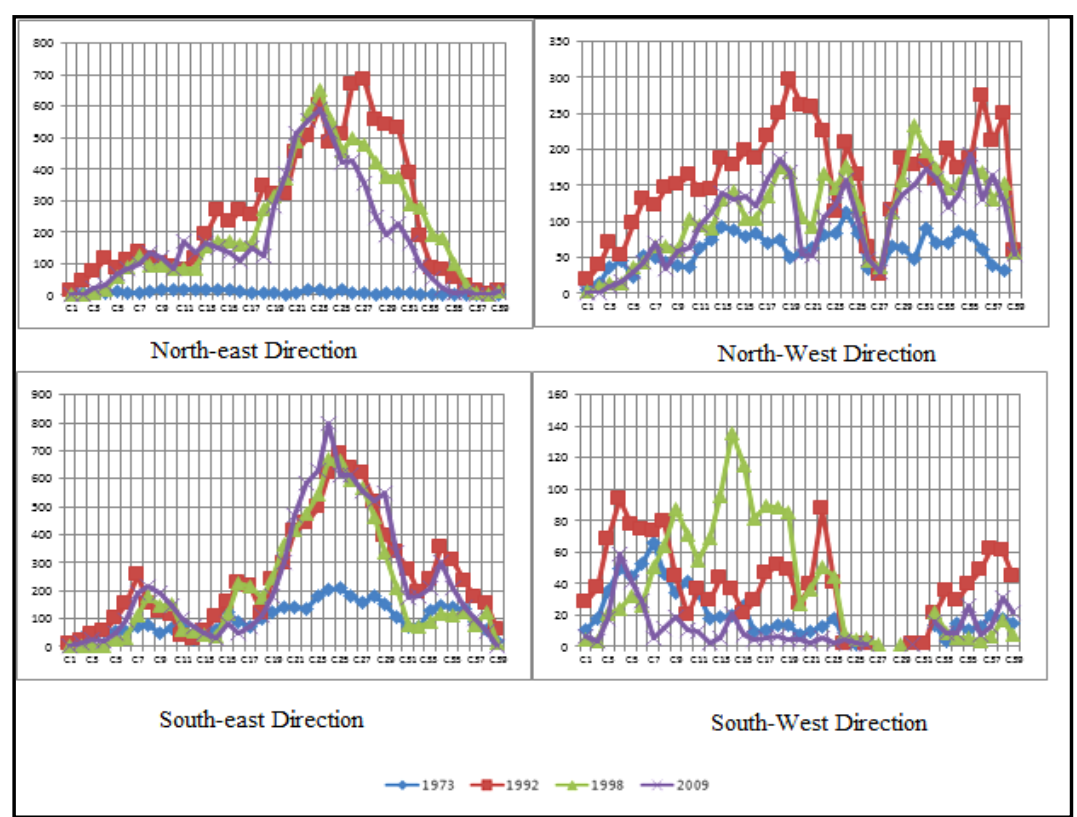

Fig. $9 b$ - Metric NP direction and Circle wise

(Note: $\mathrm{X}$ axis indicates circles considered, $\mathrm{Y}$ axis indicates the value of the metrics) 
fragmentation. The metric shows results similar to the number of patches. In NE direction, C19 and C27 show more number of urban patches, which connotes that patches are getting fragmented in time and hence higher values for the patch density were noticed in 1992 and 1998 (compared to 2009, whereas 1973 has a very low value which indicates the compact

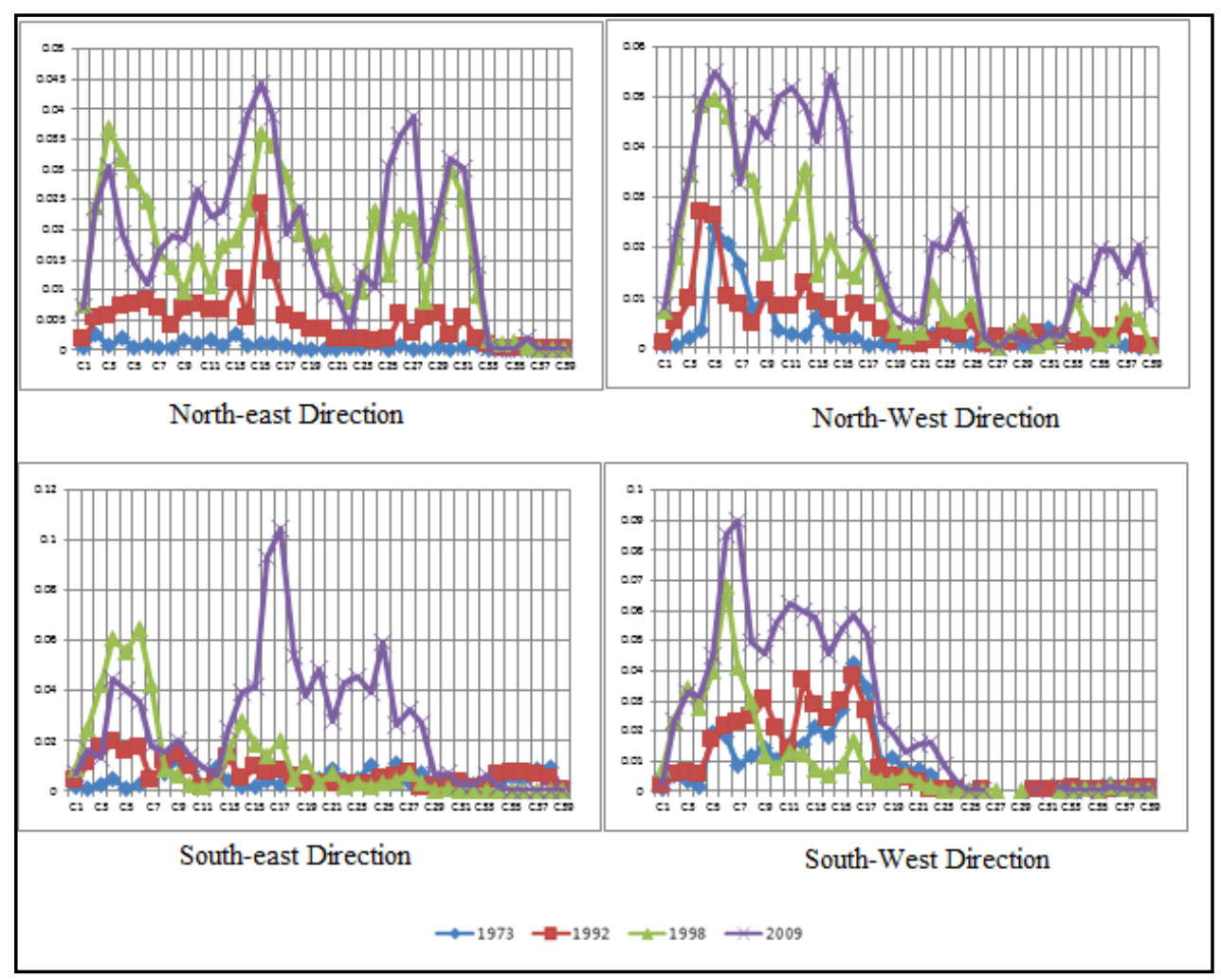

Fig. 9c-PD direction and Circle wise

(Note: $\mathrm{X}$ axis indicates circles considered, $\mathrm{Y}$ axis indicates the value of the metrics)

features of urban patches). In NW direction, patch density is varying for all circles (more variation of values were found in 1992 and 1998 compared to 2009, whereas 1973 has a very low value which indicates the compact features of urban patches). In SE and SW directions the patch density is low, which connotes to the compactness of patches except for circles (C21 to C29) in SW direction.

4.4. Largest patch index (LPI): Largest Patch Index (LPI) was computed to represent the percentage of landscape that contains the largest patch (Fig. 9d). The NE and SW directions show that the largest urban patches for the circles C13 to C20 indicate a less number of urban patches connoting to compactness of urban features (i.e., mostly in 2009). In NW and SW directions, the bigger urban patches are largely present towards the city center, connoting to more compact urban patches (i.e., circles from $\mathrm{C} 1$ to $\mathrm{C} 17$ showing maximum values for all years). 
T. V. RAMACHANDRA, H. A. BHARATH, M. V. SOWMYASHREE

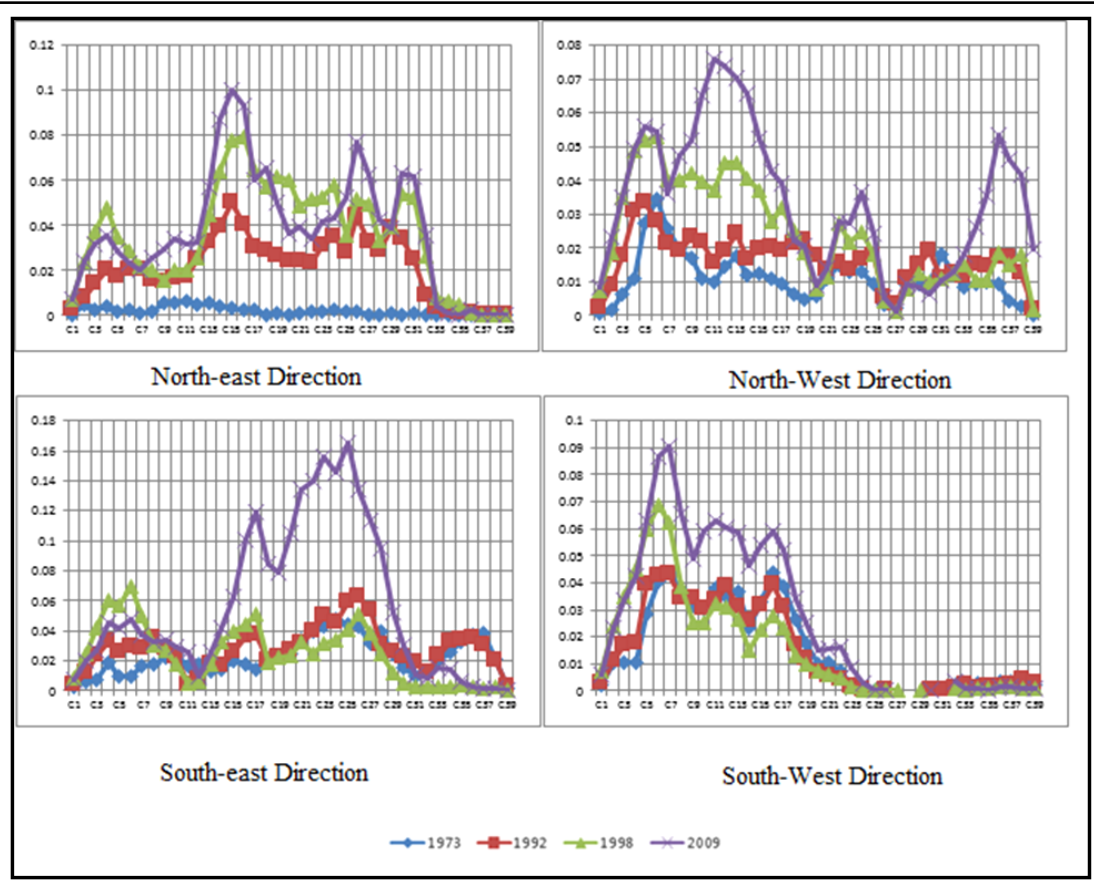

Fig. 9d-LPI direction and Circle wise

(Note: $\mathrm{X}$ axis indicates circles considered, $\mathrm{Y}$ axis indicates the value of the metrics)

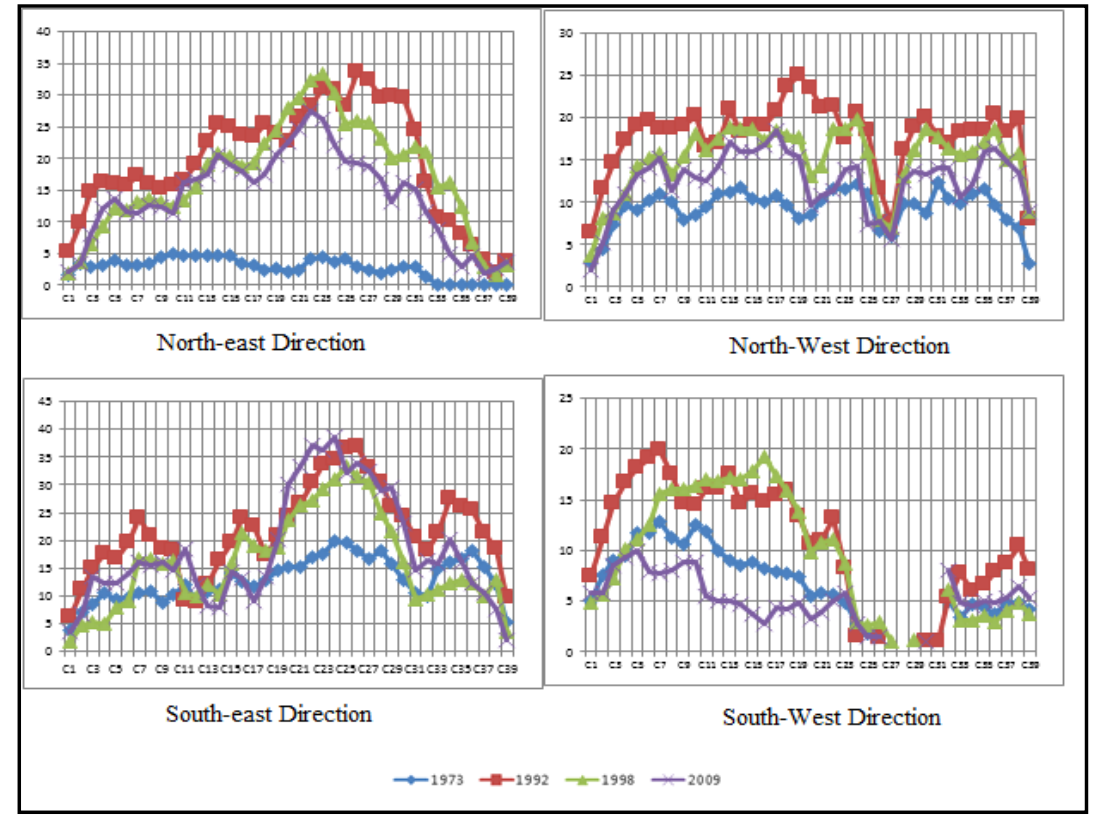

Fig. 9e - PD direction and Circle wise

(Note: $\mathrm{X}$ axis indicates circles considered, $\mathrm{Y}$ axis indicates the value of the metrics) 
4.5. Landscape shape index (LSI): Landscape shape index (Fig. 9e) provides a simple measure of class aggregation or clumpiness and it is measured via class edge surfaces. Fig $9 e$ depicts the complex structure of urban patches that are found in mid circles (circles 10 to 19) compared to the circles present in the urban center and fringes. In the NE direction, the metric value is less for the year 1973 for all circles indicating a simple structure and compact shapes, whereas the years 1992 and 1998 have maximum values compared to 2009, which implies that 2009 has compact patches compared to 1992 and 1998. Similarly, the NW direction shows a similar trend as the NE direction, i.e., 1973 shows compact features while 1992 and 1998 have maximum values compared to 2009, indicating more fragmentation in the years 1992 and 1998 for all circles. The SE direction shows a similar trend as the NE and NW direction. In SW direction, the urban patches show a simple structure for 2009 compared to 1992 and 1998 in all circles.

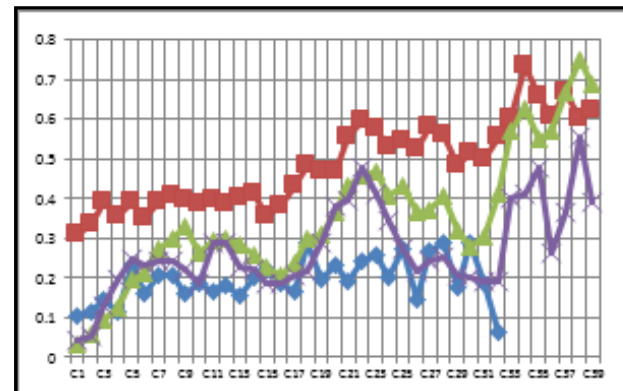

North-east Direction

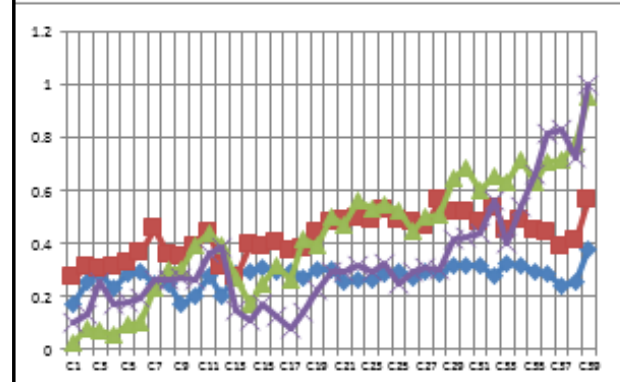

South-east Direction

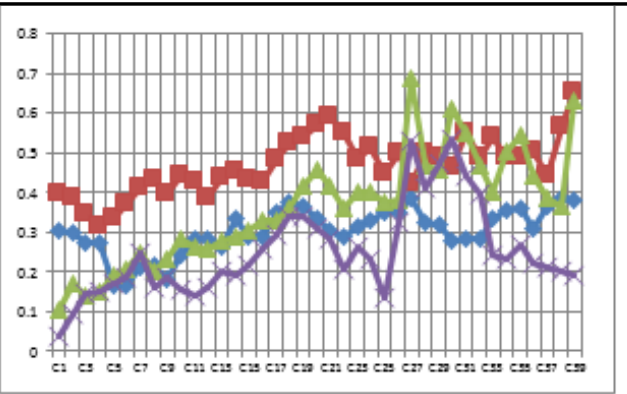

North-West Direction

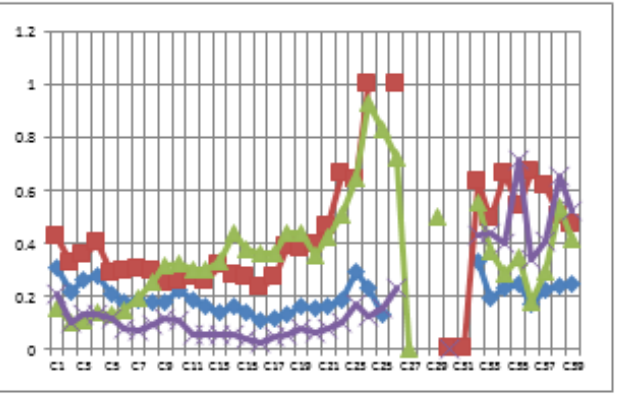

South-West Direction

$$
\rightarrow 1973 \rightarrow-1992 \rightarrow 1998 \div 2009
$$

Fig. $9 f-$ NLSI direction and Circle wise

(Note: $\mathrm{X}$ axis indicates circles considered, $\mathrm{Y}$ axis indicates the value of the metrics)

4.6. Normalized Landscape Shape Index (NLSI): Normalized Landscape Shape Index (Figure 9f) is similar to landscape shape index but this represents the normalized value. This index provides a simple measure of class aggregation or clumpiness. Figure 9 f below depicts the variations in the value and indicates that complexity of urban patches increases as it moves away from the core area. The analysis showed that the circles at the centre in 2009 were 
clumped compared to 1973, whereas circles (circle 28 onwards) show the characteristics of fragmented growth towards 2009.

4.7. Edge Density (ED): Edge Density (Fig. 9g) computes the total amount of edge present in a landscape. Edge Density (ED) represents the ratio of total edges of all the patches to total area. With increase in fragmentation, the number of patches increases and so does the number of edges. Hence edge density is the measure of fragmentation of the landscape. Figure $9 \mathrm{~g}$

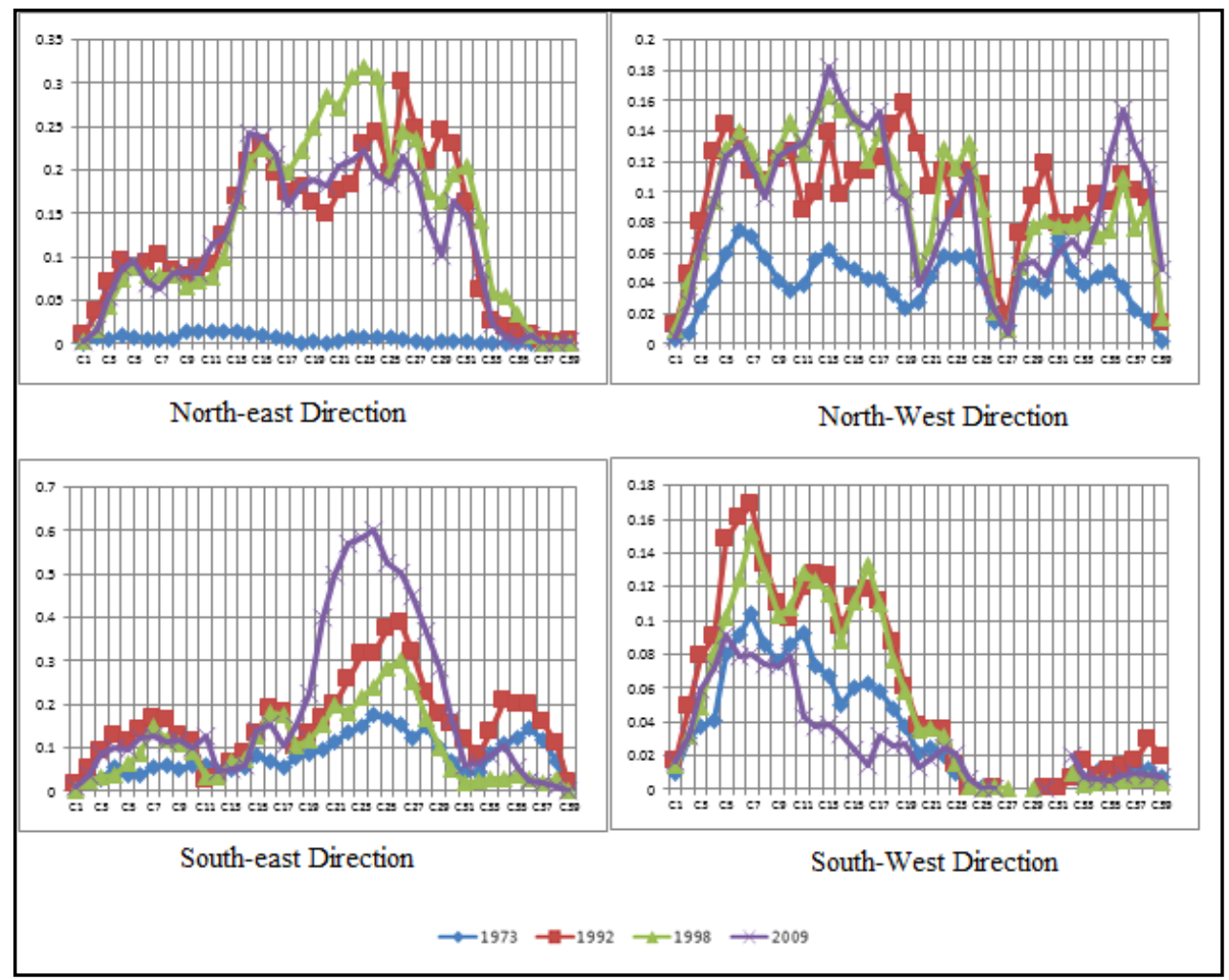

Fig. $9 g$ - ED direction and Circle wise

(Note: $\mathrm{X}$ axis indicates circles considered, $\mathrm{Y}$ axis indicates the value of the metrics)

indicates that the edge density has maximum value for the circles $\mathrm{C} 11$ to $\mathrm{C} 29$ indicating greater fragmentation (i.e., greater values found in 1992 and 1998 compared to 2009, whereas, 1973 has a very low value which indicates the compact features of urban patches). In NW direction, maximum values for all circles were found in the year 1992 and 1998 compared to 2009, indicating greater fragmentation in 1992 and 1998 compared to 2009. In SE and SW directions, the number of patches is low, which connotes to the compactness of patches, except for circles C21 to C29 in 2009 in SE direction, which indicate fragmentation.

4.8. Clumpiness index (CLUMPY): Clumpiness index (Fig. 9h) is the measure of patch aggregation. It measures the clumpiness of the overall urban patches. Clumpiness ranges from -1 to 1 , where clumpiness is equal to -1 when the urban patch type is maximally disaggregated. 


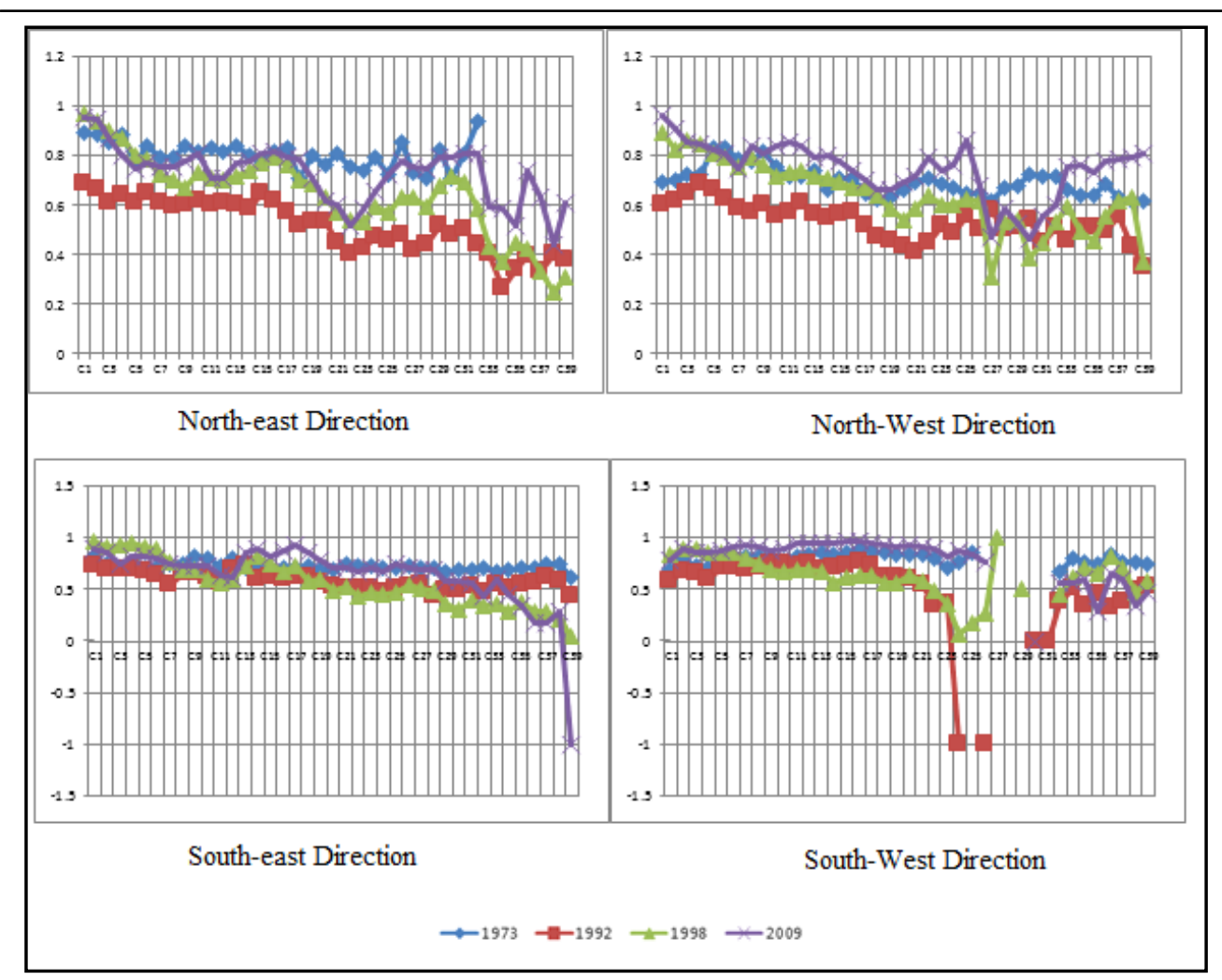

Fig. $9 h-$ ED direction and Circle wise

(Note: $\mathrm{X}$ axis indicates circles considered, $\mathrm{Y}$ axis indicates the value of the metrics)

Clumpiness is equal to 0 when the patch is distributed randomly and clumpiness approaches 1 when urban patch type is maximally aggregated. The graph shows that the value ranges from 0 to 1 , which implies that the patches are getting aggregated in time for northeast and northwest directions. SE and SW directions also show a similar trend, but C39 (SE) and C23, C25 (SW) show values of -1 indicating maximum disaggregation of urban patches.

4.9. Interspersion and Juxtaposition Index (IJI): The Interspersion and Juxtaposition Index (IJI) (Fig. 9i) measures the extent to which patch types are interspersed (not necessarily dispersed). Higher values result when the urban patch types are well interspersed (i.e., equally adjacent to each other), whereas lower values characterize landscapes in which the patch types are poorly interspersed (i.e., disproportionate distribution of patch type adjacencies) (McGarigal and Marks 1995). These metrics' analysis showed same results as that of the clumpiness index, stating that the lower values are found in the inner circles in 2009 and the higher values were near the boundary (circles 7 to 27 ).

4.10. Aggregation Index (Al): Aggregation Index (Fig. 9j) gives the similar indication as clumpiness i.e., it measures the aggregation of the urban patches. The aggregation index showed the similar trend as the clumpiness index. The aggregation index has maximum value at the city center and urban patches get disaggregated for the circles away from the city center as depicted in figure $9 \mathrm{j}$. 


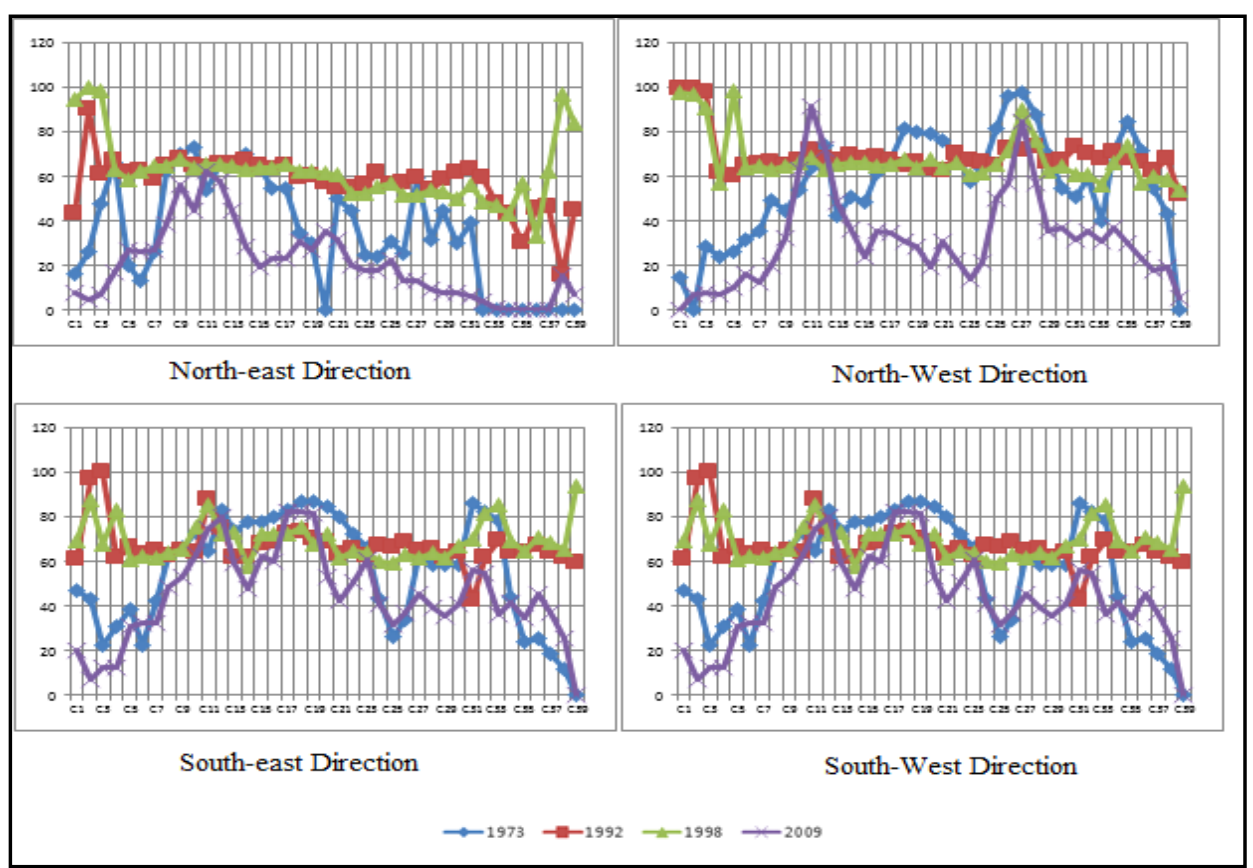

Fig. 9i - IJI direction and Circle wise

(Note: $\mathrm{X}$ axis indicates circles considered, $\mathrm{Y}$ axis indicates the value of the metrics)

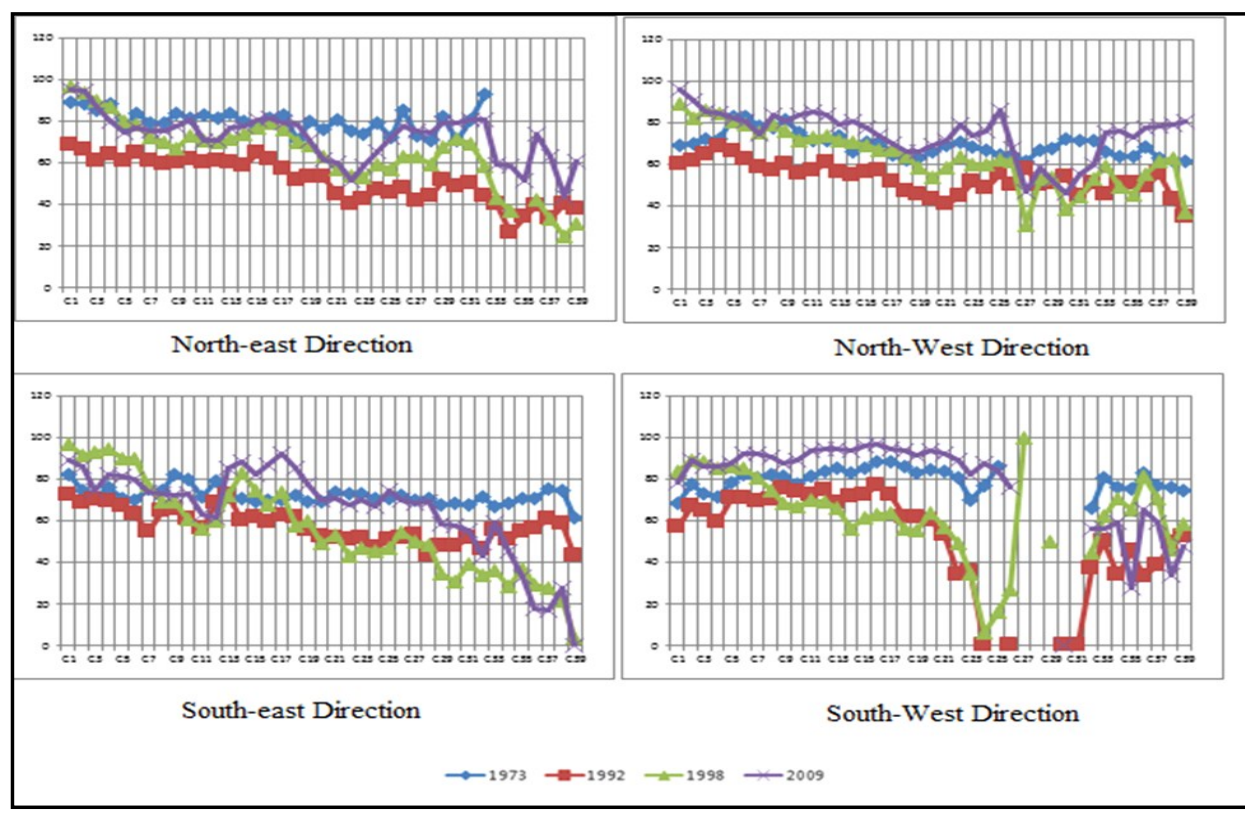

Fig. 9j - Al direction and circle wise

(Note: $\mathrm{X}$ axis indicates circles considered, $\mathrm{Y}$ axis indicates the value of the metrics) 


\section{Conclusion}

The urban footprint has been quantified considering the proportion of paved surface (built up, roads, etc.) with the reduction of other land uses. This communication discusses the urban footprint dynamics of Mumbai using multi-temporal remote sensing data with spatial metrics. Mumbai has a population density of 4583 persons per square kilometre (Census of India 2001). Mumbai urban agglomeration is ranked third after Tokyo and Mexico City. Urban dynamics was assessed using temporal remote sensing data of the period during 1973 to 2010. Vegetation declined from $53.63 \%(1973)$ to $33.76 \%$ (2009). There has been a net loss in vegetation up to $62.79 \%$ in the past four decades.

Over the past four decades, urbanization has significantly modified the land use of Mumbai city and its outskirts. The built-up area has significantly increased by $155 \%$, at the expense of nonforest land in the study region, which includes Mumbai metropolitan area with $10 \mathrm{~km}$ buffer. Urban sprawl is seen toward the southwest and northeast sectors of the metropolitan area.

The landscape metrics clearly brought out the facts of the process of urbanisation and the urban sprawl in the study region. Comparative analysis of change in built-up patch density in relation to the spread pattern indicates that all zones have relatively contributed to the development of urban area at different stages of urbanization. This analysis also reveals the infilling effects of urban development as spreading away from the urban core. These indices can provide information on urban land conversion which would help the urban planners and city development authority as a hands-on tool to understand the process and for further developmental planning.

\section{Acknowledgement}

We are grateful to NRDMS Division, The Ministry of Science and Technology, Government of India; ISRO-IISc Space Technology Cell, Indian Institute of Science; Centre for infrastructure, Sustainable Transportation and Urban Planning (CiSTUP), Indian Institute of Science for the financial and infrastructure support. Remote sensing data were downloaded from public domain (http://glcf.umiacs.umd.edu/data). We thank Mr. Susanto Sen for language editing of the manuscript and for useful suggestions.

\section{References}

AGUILERA F., VALENZUELA L., LEITAO A. (2011), Landscape metrics in the analysis of urban land use patterns: A case study in a Spanish metropolitan area, Landscape and Urban Planning 99, 226-238.

ALBERTI M., WADDELL P. (2000), An Integrated Urban Development and Ecological Model, Integrated Assessment 1, 215-227.

ANGEL S., PARENT J., CIVCO D. (2007), Urban sprawl metrics: an analysis of global urban expansion using GIS, Proceedings of ASPRS 2007 Annual Conference, May 7-11, Tampa, Florida, http://clear.uconn.edu/publications/research/tech_papers/Angel_et_al_ ASPRS2007.pdf

BHATTA B. (2009a), Analysis of urban growth pattern using remote sensing and GIS: a case study of Kolkata, India, International Journal of Remote Sensing 30, 4733-4746.

BHATTA B. (2009b), Modelling of urban growth boundary using geo informatics, International Journal of Digital Earth 2, 359-381.

BRUECKNER J. K. (2000), Urban Sprawl: Diagnosis and remedies, International Regional Science Review 23, 160-171. 
$10^{\text {th }}$ May 2013.

CHEN S., ZENG S., XIE C. (2000), Remote Sensing and GIS for urban growth analysis in China, Photogrammetric Engineering and Remote Sensing 66, 593-598.

CONGALTON R. G., ODERWALD R. G., MEAD R. A. (1983), Assessing Landsat classification accuracy using discrete multivariate analysis statistical techniques, Photogrammetric Engineering and Remote Sensing 49, 1671-1678.

CONGALTON R. G. (1991), A review of assessing the accuracy of classifications of remotely sensed data, Remote Sensing of Environment 37, 35-46.

DEFRIES R. (2008), Terrestrial vegetation in the coupled human-earth system: contributions of remote sensing, Annual Review of Environment and Resources 33, 369-390.

DUDA R. O., HART P. E., STORK D. G. (2000), Pattern Classification, A WileyInterscience Publication, Second Edition, New York.

EPSTEIN J., PAYNE K., KRAMER E. (2002), Techniques for mapping suburban sprawl, Photogrammetric Engineering and Remote Sensing 63, 913-918.

GALSTER G., HANSON R., RATCLFEE M. R. (2001), Wrestling sprawl to the ground: Defining and measuring an elusive concept, Housing Policy Debate 12, 681-717.

HAN S. S., HE C. X. (1999), Diminishing farmland and urban development in China: 1993-1996, GeoJournal 49, 257-267.

HARA Y., TAKEUCHI K., OKUBO S. (2005), Urbanization linked with past agricultural land use patterns in the urban fringe of a deltaic Asian mega-city: a case study in Bangkok, Landscape Ecology and Planning 73, 16-28.

HEROLD M., CLARKE K., SCEPAN J. (2002), The use of remote sensing and landscape metrics to describe structures and changes in urban land uses, Environment and Planning 34, 1443-1458.

HEROLD M., GOLDSTEIN N., CLARKE K. (2003), The spatiotemporal form of urban growth: measurement, analysis and modelling, Remote Sensing of Environment 86, 286-302.

HILL J., HOSTERT P., RODER A. (2004), Long-term observation of Mediterranean ecosystems with satellite remote sensing, In: Mazzoleni S., di Pasquale G., Mulligan M., di Martino P., Rego F. (Eds.), Recent Dynamics of the Mediterranean Vegetation and Landscape, John Wiley and Sons Ltd., Chichester, 33-43.

HUANG S., WANG S., BUDD W. (2008), Sprawl in Taipeisperi urban zone: Responses to spatial planning and implications for adapting global environment change, Landscape and Urban Planning 90, 20-32.

JI C. Y., LIN P., LI X., LIU Q., SUN D., WANG S. (2001), Monitoring urban expansion with remote sensing in China, International Journal of Remote Sensing 22, 1441-1455.

JI W., MA J., TWIBELL R. W., UNDERHILL K. (2006), Characterizing urban sprawl using multi-stage remote sensing images and landscape metrics, Computers, Environment and Urban Systems 30, 861-879.

JIANG F., LIU S., YUAN H., ZHANG Q. (2007), Measuring urban sprawl in Beijing with geo-spatial indices, Journal of Geographical Sciences 17, 469-478.

LICHTENBERG E., DING C. R. (2008), Assessing farmland protection policy in China, Land Use Policy 25, 59-68.

LILLESAND T. M., KIEFER R. W. (2005), Remote sensing and image interpretation, John Wiley and Sons, New York.

LIN G. C. S., HO S. P. S. (2003), China's land resources and land-use change: Insights from the 1996 land survey, Land Use Policy 20, 87-107.

LO C. P., YANG X. (2002), Drivers of land-use/land-cover changes and dynamic modelling for the Atlanta, Georgia Metropolitan Area, Photogrammetr. Eng. Remote Sens. 68, 1062-1073. 
LUCY W., PHILLIPS D. (2000), Confronting Suburban Decline, Strategic Planning for Metropolitan Renewal, Island Press, Washington, DC.

ZERAH M.-H. (2008), Splintering urbanism in Mumbai: Contrasting trends in a multi-layered society, Geoforum 39, 1922-1932.

MCGARIGAL K., MARKS B. J. (1995), FRAGSTATS: spatial pattern analysis program for quantifying landscape structure, Gen. Technical Report. PNW-GTR-351, https://ftp.fsl.orst.edu/pub/fragstats2.0, Accessed on $13^{\text {th }}$ March 2013.

PACIONE M. (2006), City profile Mumbai, Cities 23, 229-238.

MITRAKIS N. E., TOPALOGOU C. A., ALEXANDRIDIS T. K., THEOCHARIS J. B., ZALIDIS G. C. (2008), A novel self-organising neuro-fuzzy multi layered classifier for land cover classification of a VHR image, International Journal of Remote Sensing 29, 4061-4087.

NEELIMA R. (2003), Understanding slums: Case Studies for the Global Report on Human Settlements. Report submitted for UN human settlements programme, Available at: www.ucl.ac.uk/dpuprojects/Global_Report/pdfs/Mumbai.pdf.

PEISER R. (2001), Decomposing urban sprawl, Town Planning Review 72, 275-298.

PRASAD R., SINGH N., DAS K. C., GUPTA K., BHAGATT R. B. (2009), Migration to Greater Mumbai Urban Agglomeration: A Study of Characteristics of Principal Migrants and their Social Linkages, Demography India 38, 319-334.

RAMACHANDRA T. V., BHARATH A. H., DURGAPPA D. S. (2012), Insights to urban dynamics through landscape spatial pattern analysis, Int. J Applied Earth Observation and Geoinformation 18, 329-343.

FROHN R. C., HAO Y. (2006), Landscape metric performance in analyzing two decades of deforestation in the Amazon Basin of Rondonia, Brazil, Remote Sensing of Environment 100, 237-251.

YEDLA S. (2003), Urban Environmental Evolution: The Case of Mumbai, Commissioned Report Prepared for Institute for Global Environmental Strategy (IGES), Japan, Available at: http://www.seas.columbia.edu/earth/wtert/sofos/Urban_Environmental_Evolution_ The Case of Mumbai.pdf.

SUDHIRA H. S., RAMACHANDRA T. V., JAGADISH K. S. (2003), Urban sprawl pattern recognition and modelling using GIS, Paper presented at Map India, January 28-31, New Delhi, Available at: http://www.gisdevelopment.net/application/urban/sprawl/mi03142.htm.

SUDHIRA H. S., RAMACHANDRA T. V., JAGADISH K. S. (2004), Urban sprawl: metrics, dynamics and modelling using GIS, Int. J Applied Earth Observation and Geoinformation 5, 29-39.

UTTARA S., BHUVANDAS N., AGGARWAL V. (2012), Impacts of Urbanization on environment, International Journal of Research in Engineering and Applied Sciences 2, 1637 1645.

WENG Q. (2012), Remote sensing of impervious surfaces in the urban areas: Requirements, methods, and trends, Remote Sensing of Environment 117, 34-49.

YEH A. G. O., LI X. (2001), Measurement and Monitoring of urban sprawl in a Rapidly growing region using Entropy, Photogramm. Engg. and Remote Sensing 67, 83-90.

Initial submission: 26.08 .2013

Revised submission: 28.04.2014

Final acceptance: 10.06.2014

Correspondence: Indian Institute of Science, Bangalore, Karnataka, 560 012, India

E-mail: cestvr@ces.iisc.ernet.in 
